\title{
ENTREPRENEURSHIP AND FINANCIAL INSTITUTIONS MARKET ANALYSIS
}

\author{
Dr. Alex Jones \\ Professor of Leadership \\ College of Business Administration \\ American University in the Emirates (AUE) \\ Dubai, United Arab Emirates
}

\begin{abstract}
Entrepreneurship challenges become on the rise across the world. The study was conducted in the State of California studying the requirements of financial institutions towards entrepreneurs. The researcher conducted this study at banks located at the county of San Diego, California through actual interaction and observation. The main objective of the study was to study the amount of support provided by banks to new entrepreneurs. The outcome of this study has revealed that banks showed a significant level of support towards entrepreneurships. However, entrepreneurs still were faced with endearing challenges of lack of financial support from banks in the United States and all were revealed through the subjective seven main questions in this study.
\end{abstract}

Key word: Entrepreneurship, financial institutions, fictitious business name, sole proprietorship, small business administration

Cite this Article: Dr. Alex Jones, Entrepreneurship and Financial Institutions Market Analysis, International Journal of Management, 10 (4), 2019, pp. 152-158. $\mathrm{http}: / /$ iaeme.com/Home/issue/IJM?Volume $=10 \&$ Issue $=4$

\section{INTRODUCTION}

The global market uncertainty and the increased corporate ambiguity of securing a job has driven many to enroll in a course of entrepreneurship or even get a degree in such. The heightened interest in recent years has pressed business schools to focus on such a topic and start offering courses and degrees in this field (Venkataraman, 2019). The concept of entrepreneurship is on the rise across the world. Many strive for innovation and the way to do so is through owning their own businesses. Therefore, entrepreneurship is defined as owning a business that is based on innovation and it is a way of managing uncertainty in the workplace (Parker, 2018).

The concept of entrepreneurship in the United States is referred to anyone who starts his or her own business regardless of the size of the business (Drucker, 2014). The purpose of this paper is on entrepreneurship in the market of the United States of America choosing the State of California as the study area analyzing entrepreneurship and financial institutions. The main goal of the study is investigating the amount of support provided to entrepreneurs who are new start-ups trying to embrace the concept of entrepreneurship. 


\section{REVIEW OF LITERATURE}

Entrepreneurship claimed by researchers as owning a small business, self-employed, and employs others for the business (Parker, 2018). It is the new paradigm shifting that focuses on innovation in a particular field (Shumpeterian, 1955). One of the popular definitions of entrepreneurship in the business studies is the creation of an organization resulted from a seized opportunity with or without the necessary resources to do so (Bygrave \& Hofer, 1991). Therefore, the essence of entrepreneurship lies in the creation of new ventures (Parker, 2018).

Entrepreneurship is the concept of exploiting new opportunities that are based on developed inventions for the benefit of developing the economy (Rosen, 1983). It is associated with the risk-taking component of creating resources and investments (Parker, 2018). It is "the actions of entrepreneurs who seek, find and exploit profit opportunities (Corriveau 1994). Hence, it is also referred to as a process of carrying the combination of a new flavor that includes market, sources, and new products (Sharma \& Chrisman, 2007).

Economist defines entrepreneurship, in the field of industrial organization, as small firms; in labor and microeconomics, as the self-employed; in industrial organization and macroeconomics, as business owners (Parker, 2018). That being said not every business owner can be categorized as an entrepreneur (Drucker, 1985). There are certain attributes associated with the concept of entrepreneurship. The most important skills are growth mentality, flexible attitude and thinking, and innovation skills (Birch, 1987; Drucker, 1985). Therefore, entrepreneurship is behavioral approach based on intuition of an entrepreneur associated with the way they think (Drucker, 2014). Business studies associate entrepreneurship with cognitive and perceptual construct of behaviors approaches (Parker, 2018).

\section{TERMINOLOGIES}

Fictitious business name: "A business name that does not include the surname of the individual owner, and each of the partners or the nature of the business is not clearly evident by the name." (San Diego County, 2019). It is also referred to as doing business as (DBA).

Social security number: A "wallet-sized piece of paper containing unique nine-digit number assigned by the Social Security Administration and provided to every United States citizen, permanent resident, or temporary working resident." (Business Dictionary, 2019). Sole Proprietorship: "A business that legally has no separate existence from its owner. Income and losses are taxed on the individual's personal income tax return." (Entrepreneur, 2019)

Partnership: "A partnership is a formal arrangement by two or more parties to manage and operate a business and share its profits." (Investopedia, 2019)

LLC: "Like a corporation, a limited liability company or "LLC," is a separate and distinct legal entity. This means that an LLC can get a tax identification number, open a bank account and do business, all under its own name." (Legal Zoom, 2019).

Corporation: "An artificial person or legal entity created by or under the authority of the laws of a state or nation, composed, in some rare instances, of a single person and his successors, being the incumbents of a particular oltice, but ordinarily consisting of an association of numerous individuals, who subsist as a body politic under a special denomination, which is regarded In law as having a personality and existence distinct from that of its several members, and which is, by the same authority, vested with the capacity of continuous succession, irrespective of changes in its membership, either in perpetuity or for a limited term of years, and of acting as a unit or single individual in matters relating to the common purpose of the association, within the scope of the powers and authorities conferred upon such bodies by law." (The Law Dictionary, 2019). 
Employer Identification Number (EIN): It is also known as a "Federal Tax Identification Number, and is used to identify a business entity. Generally, businesses need an EIN." (Internal Revenue Services, 2019).

Small Business Administration (SBA): It is an "autonomous U.S. government agency established in 1953 to bolster and promote the economy in general by providing assistance to small businesses. One of the largest functions of the SBA is the provision of counseling to aid individuals trying to start and grow businesses." (Investopedia, 2019).

\section{OBJECTIVES OF THE STUDY}

The objective of this study was to answer the following questions:

1. Requirements to open a business bank account.

2. Minimum balance required for opening a business bank account.

3. Minimum monthly balance required in the business bank account.

4. Monthly service fees.

5. Length of time to open a business bank account.

6. Minimum required turnover of the business.

7. Level of financial support provided to new business.

\section{METHODOLOGY}

This study was conducted in the market of the State of California, United States of America. Information was gathered through face-to-face interaction with financial institutions more specifically private and union banks. There were five banks chosen as a model in this study. Bank representatives were asked the following questions: requirements to open a business bank account, minimum balance required to open a business bank account, minimum monthly balance required in the business bank account, monthly service fees, length of time to open a business account, minimum required turnover of the business, and level of financial support provided to businesses right from the start. The process of collecting information was challenging. Some banks were cooperative and others quite the opposite. This made the research data collection even more difficult as limited interaction was allowed with bank representatives.

\section{ANALYSIS}

\subsection{Requirements to open a business bank account}

The requirement to open a business bank account varied from one bank to another. The required documents regardless of the bank are as follows: government issued identification with photo (ID), social security number (SSN), tax identification, and fictitious business name statement (FBA). There seemed to be a variation of requirements towards the type of business. If the business type is sole proprietorship then fictitious business name is required. But if the owner last name is included, doing business as (DBA), then no fictitious business name is required. However, some banks did not require the additional documents since the business type is sole proprietorship. All what they needed is the social security number and the last name of owner on the business in the category of DBA. Nevertheless, the partnership type of business required Employer Identification Number (EIN). 
Table 1 Required document of opening a business bank account in the US

\begin{tabular}{|c|c|}
\hline Bank requirements & Business type \\
\hline ID & Proprietorship \\
\hline SSN & Proprietorship \\
\hline EIN & Partnership \\
\hline DBA & Proprietorship \\
\hline FBA & Proprietorship \\
\hline
\end{tabular}

\subsection{Minimum balance required for opening a business bank account}

Banks were requiring a minimum amount to open a bank account for businesses. It ranges between $\$ 25$ - \$100 (Twenty Five to a Hundred US Dollar). In fact, that was a very minimum amount requested from banks. The goal behind it is encouraging entrepreneurs to start their own businesses. It served as a motivational factor where no big amount is required to deposit with banks. The aim of most banks was to maximize businesses with less hassle given to new start-ups.

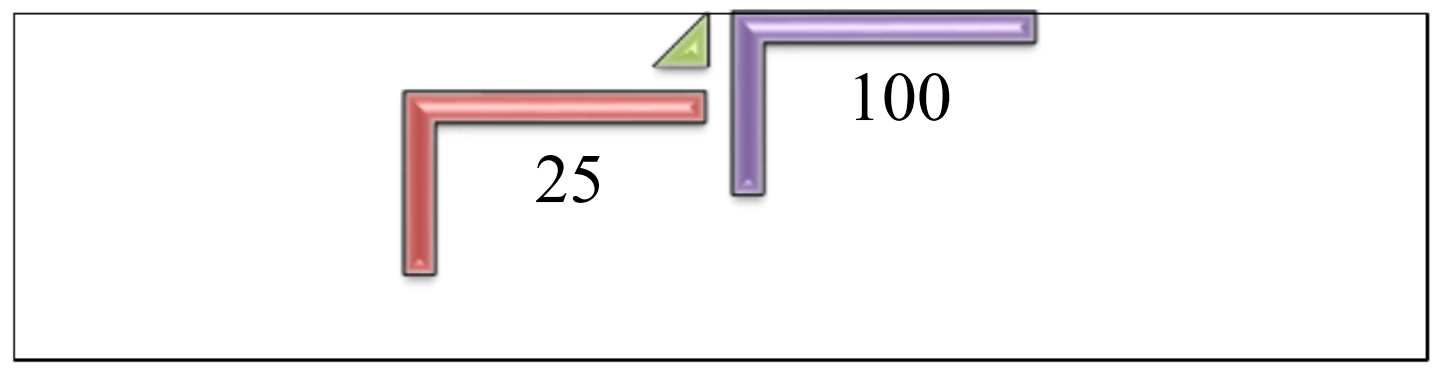

Figure 1 minimum balance in US dollar required for opening a business bank account in the US

\subsection{Minimum monthly balance required in the business bank account}

The minimum amount required by banks to be maintained without no charges ranged from none, five hundred US dollars, two thousands five hundred US dollar, three thousands US dollar, five thousands US dollar, and seven thousands US dollar.

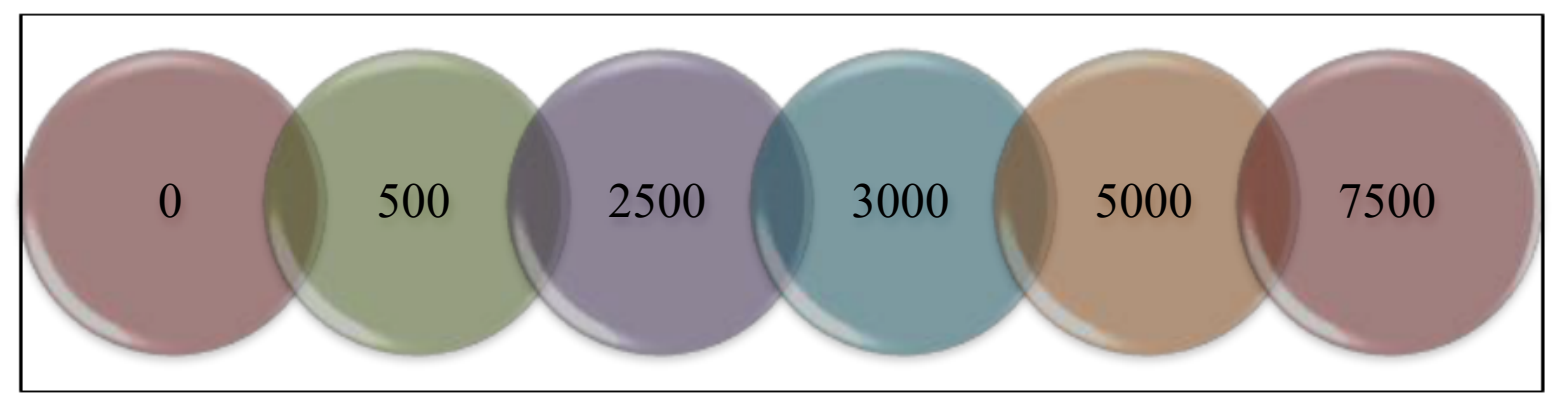

Figure 2 minimum monthly balance in US dollar required by banks in the US to maintain the business account without monthly charges

\subsection{Monthly service fees}

The monthly service fees varied among banks. Different banks had different charges. Certain banks associated their monthly service fees with the number of transactions. It was up to the limit of 150 transactions with no charges. If the number of transactions is exceeded such then fifty cents charge is applied. The monthly service charges in general were very minimal and 
ranged from eight US dollar, ten US dollar, fourteen US dollar, fifteen US dollar and sixteen US dollar.

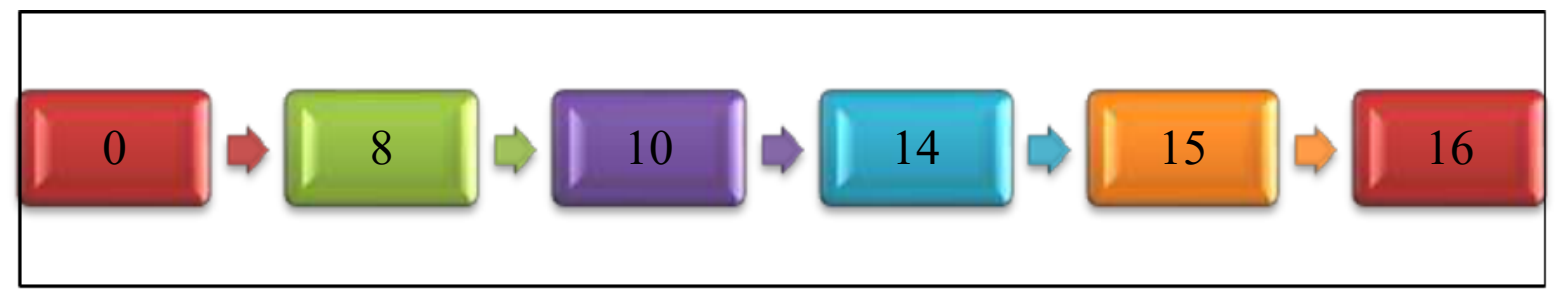

Figure 3 monthly service fees in the US dollar required by the US banks

\subsection{Length of time required for opening a business bank account}

The process of opening a business account was lucrative. It did not require a lot of time. It varied from one bank to another and ranged from 15, 30 to 60 minutes to complete the process. That's the whole required time to walk away with an active business account at hand.

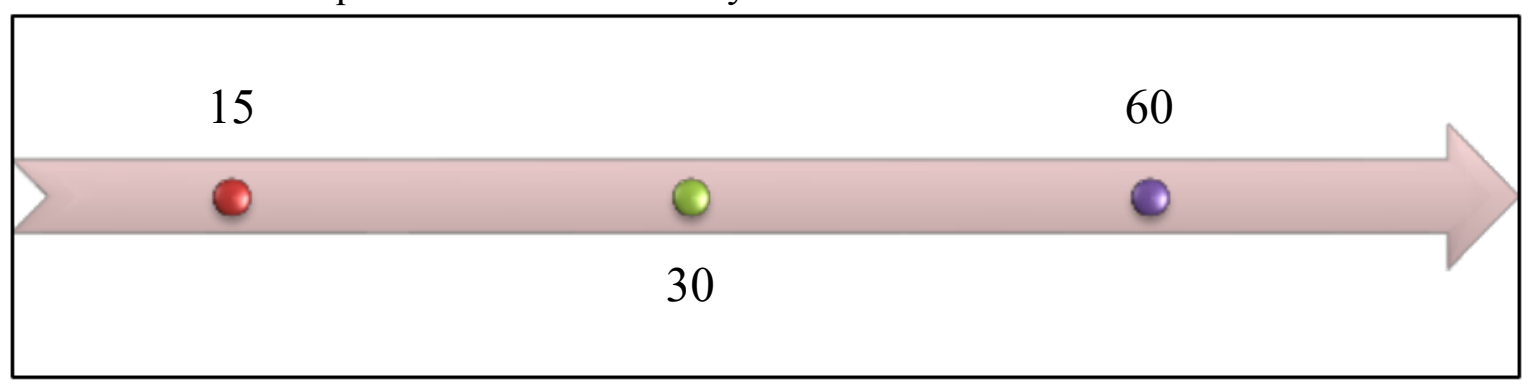

Figure 4 timeframe in minutes to open a business account by the US banks

\subsection{Minimum required turnover of the business}

There was no minimum required turnover of any business by the US banks. Entrepreneurs, in fact, can own a business account from day one even before the submission of required documents mentioned in point 6.1 .

\subsection{Level of financial support}

Apparently, US banks were not providing much financial support to new start-ups. The level of financial support varied from one bank to another. Some banks were not providing any. Others required being in business between six months to be able to apply for the Small Business Administration (SBA) loan of up to $\$ 250,000$ (Two Hundred Fifty Thousands US dollar). Some banks required a positive cash flow history of a minimum of one year then loan can be taken into consideration. Other banks required being in the business of a minimum of two years to be taken into loan consideration.

\section{CONCLUSION}

The focus of this study was to answer the main intended question of understanding the financial market of the United States and how they do support entrepreneurship. The objective of this study revolved around seven main questions: 1) requirements to open a business bank account, 2) minimum balance required for opening a business bank account, 3) minimum monthly balance required in the business bank account, 4) monthly service fees, 5) length of time to open a business account, 6) minimum required turnover of the business, and 7) level of financial support provided to new business. 
The main questions were answered sufficiently in this study. It was found that banks were supportive to entrepreneurs to certain extents. There were fewer requirements to open a bank account, which made the process a lot easier for new entrepreneurs to hit the ground running. Financial institutions and particularly private and federal banks were supportive to new startups. They required small amounts of dollars to keep in the account. The way they saw it is that any amount a new business owner can utilize for their own businesses than just keeping it in the account. They understood it was a new business and they thought they did not want to burden them with huge amount. The focus rather was on giving them more inspiration and motivation. The goal was to empower entrepreneur and get the flow of transaction in return to create a long-standing relationship.

In spite of the fact that banks were supportive from one hand with less required documents and small amount of money to keep in the account. Banks were not providing any loans on the other hand to new start-ups at the very beginning of them starting the business. There was no turnover required to open a bank account. The level of understanding was high looking at the big picture as the business completely new. The loan then would be provided on a later stage after building a trust relationship between the bank and the new business owners. They wanted to view the progress of the business for a minimum period of six months' time. Upon request, and at that stage of evaluation, banks can either provide loan directly or through SBA. The SBA is operated in the city of San Diego in California and similar administration is run throughout the same state and others accordingly.

Further research is required to be conducted in this area and time was a constraint factor in this study. The study was conducted in the city of San Diego at the State of California and covered five private and deferral financial institutions. The study can be broadened to a larger area across the same state. It can also be carried on across other states and counties. Furthermore, the study can be widened on a larger scale to cover other parts of the worlds and other continents.

\section{REFERENCES}

[1] Birch, D. L.,Job Creation in America: How Our Smallest Companies Put the Most People to Work, Free Press, New York, 1987.

[2] Business Dictionary, Retrieved from http://www.businessdictionary.com/definition/socialsecurity-card.html,2019

[3] Drucker, Innovation and entrepreneurship. Routledge, 2014

[4] Makarand Upadhyaya, Abdulsattar Abdulbaqi Alazzawi, Hatem Mohamed EL-Shishini, Deepa Chavan, The Effectiveness of Motivational Strategies on Productivity in Selected Financial Institutions in India. International Journal of Civil Engineering and Technology, 8(9), 2017, pp. 1128-1137.

[5] Drucker, P.,Innovation and Entrepreneurship, Practice and Principles, Harper \& Row, New York, 1985

[6] Entrepreneur Retrieved from https://www.entrepreneur.com/encyclopedia/soleproprietorship, 2019

[7] Internal Revenue Services, Retrieved from https://www.irs.gov/businesses/smallbusinesses-self-employed/employer-id-numbers,2019

[8] Investopedia Retrieved from https://www.investopedia.com/terms/p/partnership.asp,2019

[9] Investopedia, Retrieved from https:/www.investopedia.com/terms/s/small-businessadministration.asp,2019

[10] Legal Zoom, Retrieved from https://www.legalzoom.com/knowledge/limited-liabilitycompany/topic/limited-liability-company,2019 
[11] Parker, S. C., The economics of entrepreneurship. Cambridge University Press, 2018

[12] Schumpeter, J. A, The theory of economic development. Harvard University Press, Cambridge, 1955

[13] Lakhwinder Kaur Dhillon and Dr. Upasana Srivastava, the Role of Various Financial Institutions and Regulatory Bodies in Financial Inclusion. Journal of Management, 5(3), 2018, pp. 69-79

[14] San Diego County, Retrieved from https://arcc.sdcounty.ca.gov/Pages/fbn-info.aspx,2019

[15] Sharma, P., \& Chrisman, S. J. J., 2007. Toward a reconciliation of the definitional issues in the field of corporate entrepreneurship. In Entrepreneurship Springer, Berlin, Heidelberg, 2007, pp. 83-103

[16] The Law Dictionary Retrieved from https://thelawdictionary.org/corporation/, 2019

[17] Venkataraman, S. (2019). The distinctive domain of entrepreneurship research. In Seminal Ideas for the Next Twenty-Five Years of Advances, Emerald Publishing Limited, 2019, pp. 5-20 